\title{
Originals
}

\section{Impaired visual evoked potential and primary axonopathy of the optic nerve in the diabetic BB/W-rat*}

\author{
A.A.F. Sima ${ }^{1}$, W.-X.Zhang ${ }^{2}$, P. V.Cherian ${ }^{1}$ and S.Chakrabarti ${ }^{2}$ \\ ${ }^{1}$ Departments of Pathology and Internal Medicine and Michigan Diabetes Research and Training Center, \\ University of Michigan, Ann Arbor, Michigan, USA, and \\ ${ }^{2}$ Department of Pathology, University of Manitoba, Winnipeg, Manitoba, Canada
}

Summary. The spontaneously diabetic BB/W-rat has emerged as an important model system for somatic and autonomic diabetic polyneuropathy. In this study we examined visual evoked potentials and the presence of morphometric and structural changes in the optic nerve and the retinal ganglion cells and their afferent axons contained in the retinal nerve fibre layer. A six-month duration of diabetes mellitus was associated with significant increases in the latencies of the visual evoked potentials. The latency of the first positive potential showed a $44 \%$ increase, and that of the first negative potential was prolonged by $41 \%$. No significant changes were demonstrated at any of the amplitudes. In the optic nerve mean myelinated fibre size was significantly reduced to $82 \%$ of control values, which was accounted for by a significant reduction in axonal size. Axo-glial dysjunction, a prominent structural defect of diabetic somato-sensory neuropathy in both man and diabetic rodents, was non-significantly increased in the optic nerve. In diabetic animals retinal ganglion cells displayed dystrophic changes. No such changes were observed in age- and sex-matched control animals. Proximal axons of the retinal nerve fibre layer showed an increase in dystrophic axons in diabetic BB/W-rats. Morphometric analysis of optic nerve capillaries revealed no abnormalities except for basement membrane thickening. The present data suggest that the diabetic $\mathrm{BB} / \mathrm{W}$-rat develops a central sensory neuropathy, characterized functionally by prolonged latencies of the visual evoked potentials and structurally by an axonopathy of optic nerve fibres.

Key words: Visual evoked potential, neuropathy, optic nerve.
The spontaneously diabetic BB/W-rat has provided a valuable tool for investigating the pathogenesis and natural history of the diabetic distal symmetric sensory polyneuropathy as well as diabetic autonomic polyneuropathy [1-7]. The structural changes occurring in peripheral nerves of the $\mathrm{BB} / \mathrm{W}$-rat resemble those of human diabetic neuropathy [8] and are preceded by hyperglycaemia-induced biochemical abnormalities involving activation of the polyol-pathway and secondary changes in myo-inositol and phosphoinositide metabolism [9].

There is mounting evidence from experimental animal diabetes suggesting that the same metabolic abnormalities precede and may be responsible for the early microvascular changes in the diabetic retina. The presence of the rate limiting enzyme of the polyol-pathway, aldose reductase, has been demonstrated in several

* This study was presented in part at the 3rd International Workshop on Lessons from Animal Diabetes, Tokyo, Japan, September, 1990 retinal cell constituents such as retinal pigment epithelial cells $[10,11]$, capillary pericytes $[10-14]$, and endothelial cells $[10,11]$, and retinal ganglion cells $[10,11]$, suggesting that these cells may potentially be affected by an activated polyol pathway under hyperglycaemic conditions. Furthermore, recent data by Sredy et al. [15] have demonstrated enhanced polyol pathway activity in the optic nerve of streptozotocin diabetic rats making this central sensory pathway a potential target for secondary diabetic complications.

The consequences of the presence of aldose reductase in retinal ganglion cells of the diabetic BB/W-rat and in the optic nerve of the streptozotocin diabetic rat [15] have not been explored, but could constitute a potential basis for a primary neurosensory involvement of the optic system, as has been indicated by clinical electrophysiological data [16-19].

In order to explore this notion, functional and structural parameters of the retinal ganglion cells and their axons contained in the nerve fibre layer and the optic nerve were examined morphometrically in diabetic BB/W-rats. 
Table 1. Clinical data obtained from 6-month-old BB/W-rats and age- and sex-matched control rats

\begin{tabular}{lccc}
\hline & $\begin{array}{l}\text { Body weight } \\
(\mathrm{g})\end{array}$ & $\begin{array}{l}\text { Blood glucose } \\
(\mathrm{mmol} / \mathrm{l})\end{array}$ & $\begin{array}{l}\text { Glycated } \mathrm{Hb} \\
(\%)\end{array}$ \\
\hline $\begin{array}{l}\text { Diabetic rats } \\
(n=5)\end{array}$ & $418.8 \pm 21.1^{\mathrm{a}}$ & $21.3 \pm 2.3^{\mathrm{b}}$ & $8.7 \pm 1.4^{\mathrm{c}}$ \\
$\begin{array}{l}\text { Control rats } \\
(n=5)\end{array}$ & $516.2 \pm 7.6$ & $3.8 \pm 0.6$ & $4.7 \pm 0.3$ \\
\hline${ }^{\mathrm{a}} p<0.005 ;{ }^{\mathrm{b}} p<0.001 ;$ and ${ }^{\mathrm{c}} p<0.05$ for diabetic vs control rats
\end{tabular}

Table 2. Latencies and amplitudes of the $P_{1}, N_{1}, P_{2}$, and $N_{2}$ deflections of the visual evoked potentials in control and diabetic rats

\begin{tabular}{lllll}
\hline & \multicolumn{4}{c}{ Visual evoked potentials } \\
\cline { 2 - 5 } & $\mathrm{P}_{1}$ & $\mathrm{~N}_{1}$ & $\mathrm{P}_{2}$ & $\mathrm{~N}_{2}$ \\
\hline $\begin{array}{l}\text { Latencies }(m s) \\
\text { Diabetic rats } \\
(n=5)\end{array}$ & $19.0 \pm 0.2^{\mathrm{a}}$ & $31.2 \pm 0.6^{\mathrm{a}}$ & $45.5 \pm 3.2^{\mathrm{a}}$ & $92.5 \pm 4.9^{\mathrm{b}}$ \\
$\begin{array}{l}\text { Control rats } \\
(n=5)\end{array}$ & $13.2 \pm 0.4$ & $20.1 \pm 0.8$ & $25.0 \pm 1.6$ & $76.2 \pm 1.9$ \\
$\begin{array}{l}\text { Amplitudes }(\mu V) \\
\begin{array}{l}\text { Diabetic rats } \\
(n=5)\end{array}\end{array}$ & $10.2 \pm 1.1$ & $32.4 \pm 1.4$ & $25.6 \pm 4.1$ & $20.4 \pm 1.0$ \\
$\begin{array}{l}\text { Control rats } \\
(n=5)\end{array}$ & $9.5 \pm 1.0$ & $33.1 \pm 0.8$ & $17.8 \pm 0.9$ & $21.4 \pm 2.4$ \\
\hline${ }^{\mathrm{a}} p<0.001$ and ${ }^{\mathrm{b}} p<0.02$ for diabetic vs control rats &
\end{tabular}

\section{Materials and methods}

\section{Animals}

Non-diabetes prone male $\mathrm{BB} / \mathrm{W}$-rats and pre-diabetic age- and sexmatched BB/W-rats were obtained from the National Institutes of Health-sponsored BB/W-rat colony at the University of Massachusetts (Worcester, Mass., USA). Urine glucose concentrations were monitored daily to ascertain the onset of diabetes.

Following onset of diabetes, BB/W-rats werc supplemented with small daily doses of protamine zinc insulin (0.5-3.0 IU/day; Connaught-Novo, Inc., Toronto, Ontario, Canada) and maintained in a state of hyperglycaemia for 6 months as previously described in detail [3]. Animals were kept individually in metabolic cages with free access to water and rat chow (Wayne Lab Blox F-6, Wayne Laboratory Animal Diets, Wayne Feed Div, Chicago, Ill., USA). Urine was monitored daily with respect to both glucose and ketones (Test Tape, Eli Lilly Canada Inc., Toronto, Ontario, Canada). Blood glucose levels (Glucometer, Miles Laboratories, Ames Division, Elkhart, Ind., USA) were measured every second week, and glycated haemoglobin levels (Glycotest, Pierce Chemical Co., Rockford, Ill., USA) every month. Diabetic animals were carefully examined for the presence of cataract.

\section{Visual evoked potential}

Animals were dark-adapted overnight for visual evoked potential (VEP) recordings on the day before killing. They were sedated by i. p. injections of a mixture of ketamine hydrochloride $(100 \mathrm{mg} / \mathrm{kg}$ body weight) and acepromazine maleate $(25 \mathrm{mg} / \mathrm{kg}$ body weight). Following pupillary dilatation with $1 \%$ tropicamide and corneal anaesthesia with $0.5 \%$ proparacaine hydrochloride, VEPs were recorded from the midline of the occipital crest $(\mathrm{Oz})$, and referenced to the midline of the forehead $(\mathrm{Fz})$ using platinum subdermal electrodes (type E2; Grass Instrument Company, Quincy, Mass., USA). Responses were averaged 16 times with the aid of a VEP averager and recorded with an electro-retino-gram (ERG) recorder (Life-
Tech Instruments Inc. Houston, Tx., USA) on chart paper with pass filters set at 0.1 and $500 \mathrm{~Hz}$ and the storage time at $250 \mathrm{~ms}$. Light stimuli with an intensity of $4.82 \times 10^{-3}$ lumen $\mathrm{s}^{-1} \mathrm{~cm}^{-1}$ and a duration of $10 \mu$ s were generated at a frequency of $2 \mathrm{~Hz}$ by an ERG stimulator (Life-Tech Instruments Inc). The light source was fitted with a white diffuser and placed $0.5 \mathrm{~m}$ from the head of the animal.

\section{Tissue collection}

After 6 months of diabetes animals were anaesthetized with sodium phenobarbital ( $50 \mathrm{mg} / \mathrm{kg}$ body weight, i. p.) and killed by whole body perfusion with 0.1 mol/l cacodylate buffered ( $\mathrm{pH} 7.4$ ) $2.5 \%$ gluteraldehyde. The intracranial portion of the right optic nerve and the retina were dissected and post-fixed in the same fixative at $4{ }^{\circ} \mathrm{C}$ for $2 \mathrm{~h}$. Tissues were then post-fixed in cacodylate buffered (pH 7.4) $1 \%$ osmium tetroxide, dehydrated in a graded series of alcohol, embedded in Epon, and examined electron microscopically.

\section{Morphometric analysis}

Morphometric studies were performed with the aid of a 7872A HP digitizer, 9825A HP desktop computer, and 7225HP plotter (Hewlett-Packard Co., Cupertino, Calif., USA). Electronmicrographs with a magnification of 7000 times were used to measure the area of 1000 systematic randomly selected cross-sectioned myelinated fibres and the area of the corresponding neuropil from each optic nerve. These measurements were used to calculate mean myelinated fibre size, fibre size frequency distribution and fibre density as earlier described in detail [8]. Electronmicrographs with a magnification of 23,200 times were used to calculate the axon-myelin ratio, defined as the linear regression between the $\log$ of the cross-sectional axonal area $\left(\mu \mathrm{m}^{2}\right)$ and the number of the myelin lamellae [2]. From longitudinally sectioned optic nerves the frequency of swollen axons (defined as an axonal expansion in excess of $150 \%$ of normal) were examined and expressed as a percentage of examined fibres. Furthermore from the same sections a mean of $16.2 \pm 1.4$ nodes of Ranvier were identified in each optic nerve and the presence of axoglial junctions between paranodal myelin loops and the axolemma was examined using a magnification of 27,420 times. The frequency
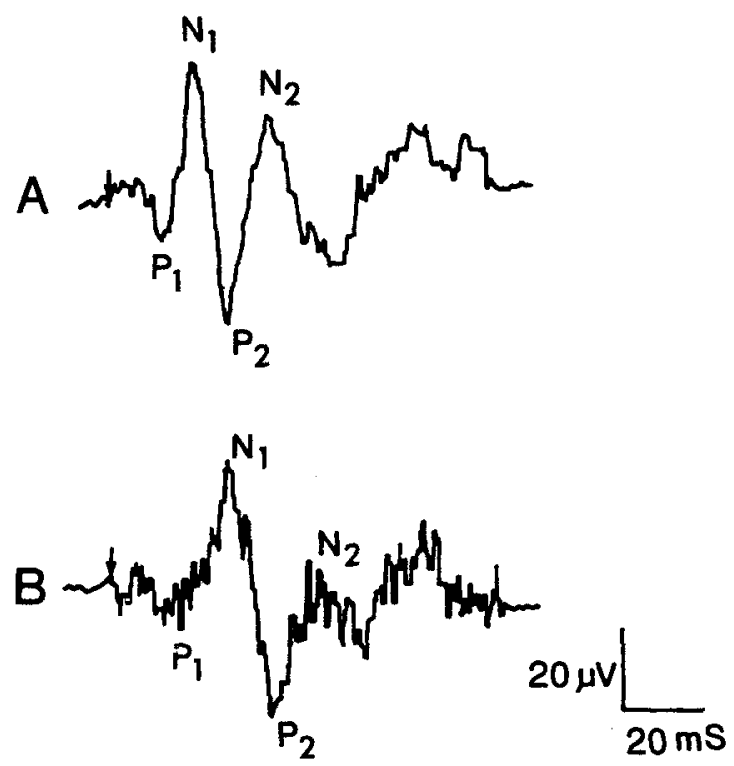

Fig.1A,B. Visual evoked potential recordings from a non-diabetic control rat $\mathbf{A}$ and a 6-month diabetic BB/W-rat $\mathbf{B}$. The arrows indicate the stimuli. In the diabetic rat note prolonged latencies of both the positive $\left(\mathrm{P}_{1}\right.$ and $\left.\mathrm{P}_{2}\right)$ and negative $\left(\mathrm{N}_{1}\right.$ and $\left.\mathrm{N}_{2}\right)$ deflections. The amplitudes were not altered in diabetic rats 


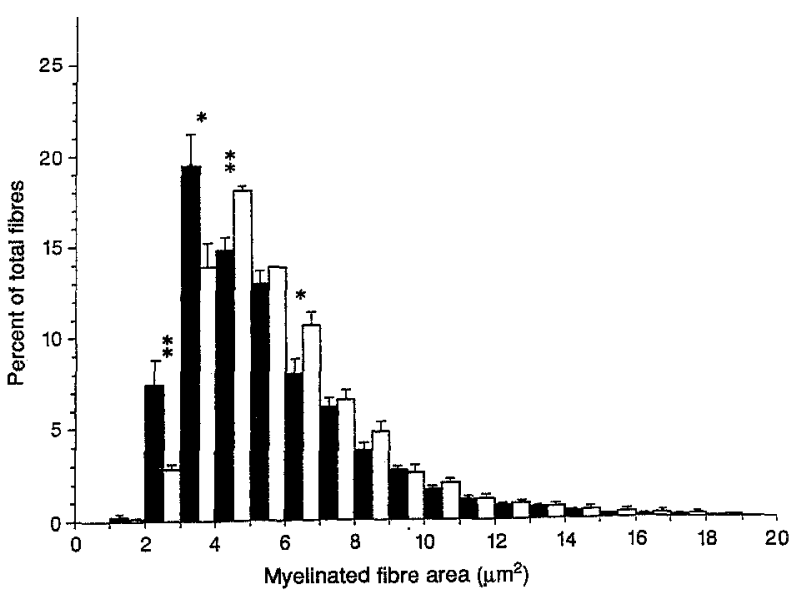

Fig. 2. The fibre-size histogram of myelinated optic nerve fibres was significantly shifted toward smaller fibre sizes in diabetic rats ( $\boldsymbol{\square})$ compared to age-matched control BB/W-rats $(\square)$. Differences between individual size frequencies; * $p<0.05$, ${ }^{* *} p<0.01$

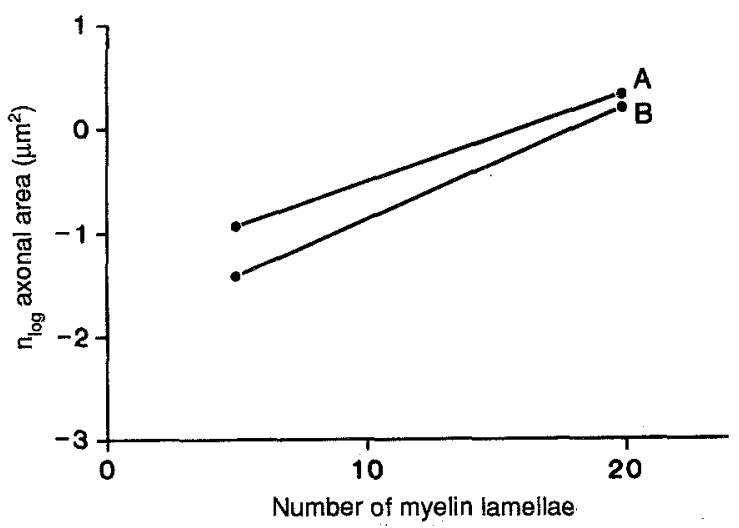

Fig. 3. The axon-myelin ratio was significantly decreased in diabetic rats compared to control rats. The intercepts (A) of the regressions were $-1.91 \pm 0.14$ vs $-1.49 \pm 0.05$ respectively; $p<0.01$. The slopes (B) were $0.110 \pm 0.003$ in diabetic vs $0.090 \pm 0.003$ in control rats; $p<0.002$

of myelin loops devoid of axo-glial junctions was expressed as \% axo-glial $d y s$-junction as previously described in detail [3]. Retinal ganglion cells as well as the proximal axons contained in the nerve fibre layer were examined for the presence of dystrophic changes, such as neurofilament accumulation, tubulovesicular profiles, electron dense bodies and lamellar bodies. These changes were expressed as percentages of the total number of ganglion cells or axons examined [6].

For the morphometric analysis of the optic nerve microvasculature the method of McEwen et al. [20] was used. Electronmicrographs with a total magnification of 10,880 times of ten randomly selected transversely sectioned capillaries from each optic nerve were examined. The parameters investigated included basement membrane thickness, the relative endothelial cell, pericyte and luminal areas expressed as percentages of the total capillary area. In addition, the number of endothelial cells and pericyte profiles per capillary was examined from the same electronmicrographs.

\section{Statistical analysis}

Results were expressed as mean \pm SEM, and the significance $(p<0.05)$ of differences between groups was calculated by the Student's $t$-test. Recognizing the number of group comparisons performed with respect to dystrophic and capillary changes, a more conservative limit for statistical significance was adopted $(p<0.02)$.

\section{Results \\ Clinical data}

Diabetic rats showed after 6 months of diabetes reduced body weights $(p<0.005)$, elevated blood glucose levels $(p<0.001)$ and elevated glycated haemoglobin values $(p<0.05)$ compared to age-matched non-diabetic control rats (Table 1). There was no evidence of cataract present in any of the diabetic rats.

Visual evoked potential. A six-month duration of diabetes was associated with prolonged latencies. The latencies of the first and the second positive deflections $\left(\mathrm{P}_{1}\right.$ and $\left.\mathrm{P}_{2}\right)$ were prolonged with $44 \% \quad(p<0.001)$ and $48 \%$ $(p<0.001)$ respectively, and those of the negative deflections $\left(\mathrm{N}_{1}\right.$ and $\left.\mathrm{N}_{2}\right)$ with $41 \%(p<0.001)$ and $20 \%$ $(p<0.02)$ respectively (Fig. 1 ; Table 2$)$, suggesting a slowed conduction velocity of the optic conducting system. The amplitudes of the positive $\left(\mathrm{P}_{1}\right.$ and $\left.\mathrm{P}_{2}\right)$ and negative $\left(\mathrm{N}_{1}\right.$ and $\left.\mathrm{N}_{2}\right)$ deflections of the VEP were not significantly altered compared to non-diabetic control rats (Table 2).

\section{Morphometric changes of the optic nerve}

Mean myelinated fibre size of the optic nerve was significantly decreased in diabetic $\mathrm{BB} / \mathrm{W}$-rats $(p<0.05)$ (Table 3); and the fibre size distribution was shifted to-

Table 3. Morphometric data of the optic nerve in 6-month-old diabetic BB/W-rats and age-matched control rats

\begin{tabular}{lllll}
\hline & $\begin{array}{l}\text { Fibre size } \\
(\mu \mathrm{m})\end{array}$ & $\begin{array}{l}\text { Density } \\
\left(\times 10^{3} / \mathrm{mm}^{2}\right)\end{array}$ & $\begin{array}{l}\text { Axonal } \\
\text { swelling } \\
(\%)\end{array}$ & $\begin{array}{l}\text { Axo-glial } \\
\text { dysjunction } \\
(\%)\end{array}$ \\
\hline $\begin{array}{l}\text { Diabetic rats } \\
(n=5)\end{array}$ & $1.9 \pm 0.06^{\mathrm{a}}$ & $311.3 \pm 13.4$ & $4.8 \pm 0.8$ & $2.5 \pm 1.1$ \\
$\begin{array}{l}\text { Control rats } \\
(n=5)\end{array}$ & $2.32 \pm 0.2$ & $276.0 \pm 10.0$ & $2.8 \pm 1.0$ & $0.6 \pm 0.8$ \\
\hline${ }^{\mathrm{a}} p<0.05$ for diabetic vs control rats & &
\end{tabular}

Table 4. Dystrophic changes (\%) in ganglion cells and proximal axons

\begin{tabular}{|c|c|c|c|c|}
\hline & $\begin{array}{l}\text { Tubulo- } \\
\text { vesicular } \\
\text { changes }\end{array}$ & $\begin{array}{l}\text { Lamellar } \\
\text { mem- } \\
\text { branes }\end{array}$ & $\begin{array}{l}\text { Neuro- } \\
\text { filament } \\
\text { accumu- } \\
\text { lation }\end{array}$ & $\begin{array}{l}\text { Electron } \\
\text { dense } \\
\text { bodies }\end{array}$ \\
\hline \multicolumn{5}{|l|}{ Ganglion cells } \\
\hline $\begin{array}{l}\text { Diabetic rats } \\
(n=5)\end{array}$ & $5.2 \pm 2.2$ & $0.8 \pm 0.6$ & $2.5 \pm 1.0$ & $0 \pm 0$ \\
\hline $\begin{array}{l}\text { Control rats } \\
(n=5)\end{array}$ & $0 \pm 0$ & $0 \pm 0$ & $0 \pm 0$ & $0 \pm 0$ \\
\hline \multicolumn{5}{|l|}{ Proximal axons } \\
\hline $\begin{array}{l}\text { Diabetic rats } \\
(n=5)\end{array}$ & $0.3 \pm 0.2$ & $0 \pm 0$ & $0.6 \pm 0.8^{\mathrm{a}}$ & $0.8 \pm 0.2$ \\
\hline $\begin{array}{l}\text { Control rats } \\
(n 5)\end{array}$ & $0 \pm 0$ & $0 \pm 0$ & $0 \pm 0$ & $0.2 \pm 0.3$ \\
\hline
\end{tabular}




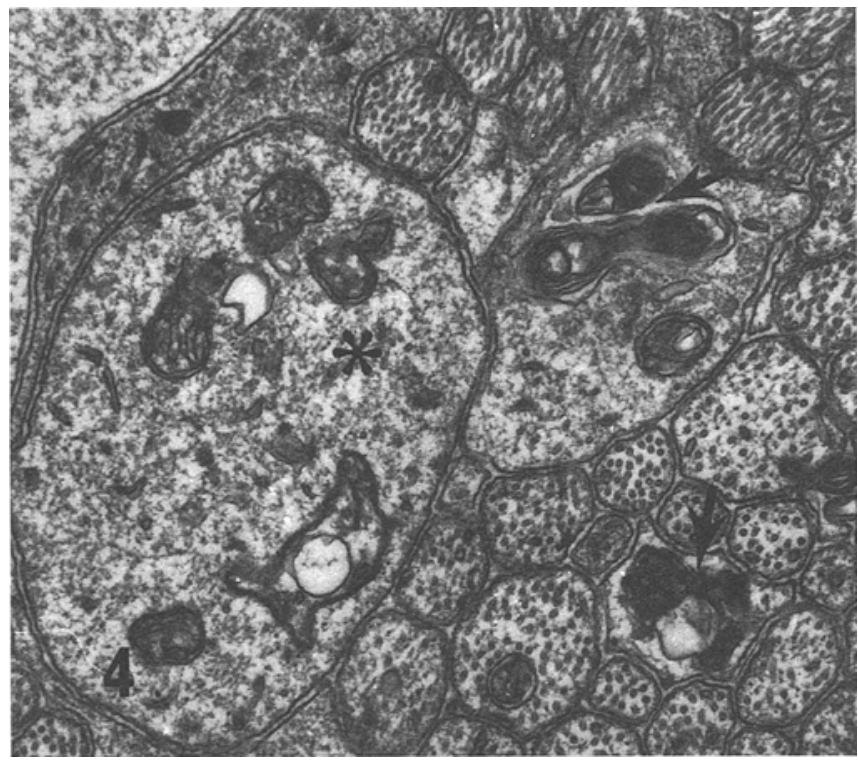

Fig.4. Expanded axons in the nerve fibre layer of a 6-month-old diabetic rat displaying neurofilament accumulation (*), and electron dense bodies (arrows). Magnification 12,270 $\times$

ward smaller fibre sizes (Fig.2). No differences could be demonstrated between diabetic and non-diabetic control rats with respect to myelinated fibre density (Table 3 ). Calculation of the axon-myelin ratio revealed a significant change in the relationship between axonal area and myelin thickness in diabetic rats, indicating significant axonal atrophy as compared to non-diabetic control rats (Fig.3).

The frequency of swollen axons showed a $70 \%$ nonsignificant increase in diabetic rats (Table 2). Axo-glial dysjunction, a characteristic para-nodal change in diabetic neuropathy, showed a four-fold non-significant increase in diabetic rats (Table 3 ).

\section{Dystrophic changes}

Ultrastructural examination of retinal ganglion cells displayed dystrophic changes in diabetic $\mathrm{BB} / \mathrm{W}$-rats in contrast to age-matched control rats who revealed no such changes (Table 4). These changes consisted of tubulovesicular changes, neurofilament accumulations, and lamellar membranous profiles (Table 4).

Proximal axons contained in the nerve fibre layer of the retina revealed the presence of significant dystrophic changes, such as neurofilament accumulations $(p<0.01)$ and electron-dense bodies $(p<0.02)$ of the axon (Fig. 4; Table 4). No dystrophic changes were demonstrated in the optic nerve.

\section{Vascular morphometry}

Capillary basement thickness was increased by $30 \%$ in diabetic optic nerves $(p<0.01)$ (Table 5$)$. No differences were obtained with respect to pericyte, endothelial cell or Iuminal profile areas, nor did optic nerve capillaries reveal any qualitative abnormalities of endothelial cells or pericytes or changes in pericyte or endothelial cell numbers in diabetic BB/W-rats (Table 5).

\section{Discussion}

The present study of the diabetic optic nerve has demonstrated myelinated fibre atrophy secondary to axonal atrophy as indicated by decreased axon-myelin ratio. These structural changes of the optic system were accompanied by a significant slowing of the relay of the electrical impulse as indicated by prolonged latencies of the VEP, although the amplitudes were not altered. The prolonged latencies may, at least in part, be explained by the nerve fibre atrophy of the optic nerve. However, other as yet unexplored factors, such as synaptic abnormalities $[4,6]$ as well as abnormalities of the second neuron and its projection to the visual cortex may conceivably contribute to the delay in the propagation of the impulse.

In diabetic peripheral neuropathy various electrophysiological abnormalities can be accounted for by nodal changes. In the $\mathrm{BB} / \mathrm{W}$-rat the acute reversible slowing of nerve conduction velocity has been attributed to a diminished nodal equilibrium potential owing to intraaxonal sodium accumulation associated with nodal axonal swelling [2]. These early changes in the diabetic peripheral nerves have been related to the polyol-pathway induced $\mathrm{Na} / \mathrm{K}$-ATPase defect and are fully normalized following insulin-treatment, aldose reductase inhibition-treatment, or myo-inositol supplementation [21]. The progressively less readily reversible conduction defect in peripheral nerves of the chronically diabetic BB/W-rat has been directly associated with the progressive loss of paranodal axo-glial junctions [3] which constitute a structural barrier system believed to be responsible for maintaining a high concentration of nodal sodium-channels, necessary for

Table 5. Morphometric parameters of optic nerve capillaries in 6-month-old diabetic and non-diabetic BB/W-rats expressed as percentage of total capillary area

\begin{tabular}{lllllll}
\hline & $\begin{array}{l}\text { Basement mem- } \\
\text { brane thickness }(\mathrm{nm})\end{array}$ & $\begin{array}{l}\text { \% Pericyte } \\
\text { profile area }^{\mathrm{a}}\end{array}$ & $\begin{array}{l}\text { \% Endothelial } \\
\text { cell profile area }\end{array}$ & $\begin{array}{l}\text { \% Luminal } \\
\text { area }^{\mathrm{a}}\end{array}$ & $\begin{array}{l}\text { Number of } \\
\text { pericyte profiles }\end{array}$ & $\begin{array}{l}\text { Number of } \\
\text { endothelial cells }\end{array}$ \\
\hline $\begin{array}{l}\text { Diabetic rats } \\
(n=5)\end{array}$ & $181.0 \pm 8.2^{\mathrm{b}}$ & $5.4 \pm 1.6$ & $11.1 \pm 1.5$ & $70.2 \pm 4.3$ & $3.54 \pm 0.26$ & $1.90 \pm 0.03$ \\
$\begin{array}{l}\text { Control rats } \\
(n=5)\end{array}$ & $138.8 \pm 5.2$ & $7.1 \pm 0.7$ & $10.2 \pm 1.2$ & $71.6 \pm 1.2$ & $3.70 \pm 0.53$ & $2.15 \pm 0.13$ \\
\hline
\end{tabular}

a denotes percent of total capillary area; ${ }^{b} p<0.01$ for diabetic vs control rats 
the generation of electrical impulse [22]. In the present study we demonstrated a non-significant $70 \%$ increase in the frequency of axonal swelling and a four-fold but nonsignificant increase in axo-glial dysjunction in diabetic optic nerve fibres. These findings may suggest that either these characteristic structural changes of peripheral nerve in diabetes do not occur in central sensory nerve tracts or that they occur only after a longer exposure to hyperglycaemia. In this context it is noteworthy that in the central sensory axon of the dorsal root ganglion cell structural changes similar to those of the peripheral axon occur later and at a slower pace [23], suggesting that central pathways may be partially protected against the adverse effects of hyperglycaemia.

The suggestive quantitative increase in structural changes of retinal ganglion cells and their proximal axons contained in the retinal nerve fibre layer are collectively referred to as neuroaxonal dystrophic changes $[6,24]$. Changes such as neurofilament accumulations, electron dense bodies, tubulovesicular changes, and lamellar membraneous profiles are seen at the two extreme ends of the neuroaxonal axis in a variety of neuropathies [25-29] including experimental diabetic neuropathy $[4,6,30-32]$. It has been suggested that these dystrophic changes may reflect abnormal axonal transport and/or aberrant phosphorylation of neuroskeletal components $[6,33]$. Neuroaxonal dystrophic changes appear to be a generalized abnormality affecting both somatic and autonomic nerves in the diabetic rat $[4,6,30,32]$, and as our studies $[6,23]$, and those of others [34] have suggested may be associated with the characteristic axonal atrophy seen in diabetic neuropathy both in man and experimental animal models $[35,36]$.

The present findings in the diabetic optic nerve, although more subtle, appear to be similar to those previously described in peripheral nerve in this animal model. The presence of an amenable polyol-pathway in the optic nerve [15], may suggest a common underlying mechanism.

However, a microvascular element in the genesis of diabetic optic neuropathy should not be totally ignored, since the abnormalities described in ganglion cell somata located in the retina could conceivably be mediated by the consequences of retinal microvasculopathy. The scarcity of microvascular changes in the optic nerve, however would seem to favour a primary metabolic insult affecting the neuroaxonal apparatus of the optic system.

Acknowledgements. This study was supported in part by grants from the Medical Research Council of Canada (MT-10673, MA10674) and USPHS Research grant RO1- (DK43884-01). Dr. S. Chakrabar$\mathrm{t} i$ is a recipient of a post-doctoral fellowship from Diabetes Canada. The authors are indebted to Ms. A.McArthur and Ms. E. Moore for preparing the manuscript.

\section{References}

1. Sima AAF (1985) Can the BB-rat help to unravel diabetic neuropathy? Annotation. Neuropath Appl Neurobiol 11: 253-264

2. Sima AAF, Brismar T (1985) Reversible diabetic nerve dysfunction: structural correlates to electrophysiological abnormalities. Ann Neurol 18: 21-29
3. Sima AAF, Lattimer SA, Yagihashi S, Greene D (1987) Axoglial dysjunction. A novel structural lesion that accounts for poorly reversible slowing of nerve conduction in the spontaneously diabetic BB-rat. J Clin Invest 77: 474-484

4. Yagihashi S, Sima AAF (1985) Diabetic autonomic neuropathy in the BB-rat. Ultrastructural and morphometric changes in sympathetic nerves. Diabetes 34: 558-564

5. Yagihashi S, Sima AAF (1986) Diabetic autonomic neuropathy in the BB-rat. Ultrastructural and morphometric changes in parasympathetic nerves. Diabetes 35: 733-743

6. Yagihashi S, Sima AAF (1986) Neuroaxonal and dendritic dystrophy in diabetic autonomic neuropathy. J Neuropath Exp Neurol 45: 545-565

7. McEwen TAJ, Sima AAF (1987) Autonomic neuropathy in the BB-rat. Assessment by an improved method for measuring heart rate variability. Diabetes 36: 251-255

8. Sima AAF, Nathaniel V, Bril V, McEwen TAJ, Greene, DA (1988) Histopathological heterogeneity of neuropathy in insulindependent and non-insulin-dependent diabetes, and demonstration of axo-glial dysjunction in human diabetic neuropathy. J Clin Invest 81:349-364

9. Greene DA, Lattimer SA, Sima AAF (1987) Sorbitol, myo-inositol and sodium-potassium ATPase in the pathogenesis of diabetic complications. N Engl J Med 316: 599-606

10. Chakrabarti S, Sima AAF (1987) Pathogenetic heterogeneity in retinal capillary basement membrane thickening in the diabetic BB-rat. Diabetologia 30:966-968

11. Chakrabarti S, Sima AAF, Nakajima S, Yagihashi S, Greene DA (1987) Aldose reductase in the BB-rat. Isolation, immunological identification and localization in the retina and peripheral nerve. Diabetologia 30: 244-251

12. Akagi Y, Kador PF, Kuwabara T, Kinoshita JH (1983) Aldose reductase localization in human retinal mural cells. Invest Ophthalmol Vis Sci 24: 1516-1519

13. Hohman TC, Nishimura C, Robison WG Jr (1989) Aldose reductase and polyol in cultured pericytes of human retinal capillaries. Exp Eye Res 48: 55-60

14. Buzney SM, Frank RN, Varma SD, Tanishima T, Gabbay KH (1977) Aldose reductase in retinal mural cells. Invest Ophthalmol Vis Sci 16: 392-396

15. Sredy J, Sawicki DR, Notrest RR (1991) Polyol pathway activity in nervous tissues of diabetic and galactose-fed rats: effect of dietary galactose withdrawal or tolrestat intervention therapy. $\mathbf{J}$ Diab Complications 5: 42-47

16. Yamazaki H, Adachi-Usami E, Chiba J (1982) Contrast thresholds of diabetic patients determined by VECP and psychological measurements. Acta Ophthalmol 60:386-392

17. Puvanendran K, Devathasan G, Wong PK (1983) Visual evoked responses in diabetes. J Neurol Neurosurg Psychiatry 46: 643647

18. Bresnick GH (1986) Diabetic retinopathy viewed as a neurosensory disorder. Arch Ophthalmol 104: 989-990

19. Algan M, Ziegler O, Gehin PH et al. (1989) Visual evoked potentials in diabetic patients. Diab Care 12: 227-229

20. McEwen TAJ, Chakrabarti S, Sima AAF (1987) A rapid reproducible method for determination of basement membrane thickness in biological structures. Comput Biol Med 14: 586-592

21. Greene DA, Chakrabarti S, Lattimer SA, Sima AAF (1987) Role of sorbitol accumulation and myoinositol depletion in paranodal swelling of large myelinated nerve fibers in the insulindeficient spontaneously diabetic biobreeding rat. J Clin Invest 79: 1479-1485

22. Brismar T, Sima AAF, Greene DA (1987) Reversible and irreversible nodal dysfunction in diabetic neuropathy. Ann Neurol 21: 504-507

23. Sima AAF, Yagihashi S (1986) Distal central axonopathy in the spontaneously diabetic BB-Wistar rat. A sequential ultrastructural and morphometric study. Diab Res Clin Prac 1: 289-298

24. Lampert PW (1967) A comparative electron microscopic study of reactive, degenerating, regenerating, and dystrophic axons. J Neuropathol Exp Neurol 26: 345-368 
25. Hedley-White ET, Gilles FH, Uzman BG (1968) Infantile neuroaxonal dystrophy: a disease characterized by altered terminal axons and synaptic endings. Neurology 18: 891-906

26. Williamson K, Sima AAF, Curry B, Ludwin SK (1982) Neuroaxonal dystrophy in young adults: a clinicopathological study of two unrelated cases. Ann Neurol 11:335-343

27. Cork LC, Troncoso JC, Prine DL, Stanley EF, Griffin JW (1983) Canine neuroaxonal dystrophy. J Neuropathol Exp Neurol 42: 286-296

28. Prineas JW (1969) The pathogenesis of dying-back polyneuropathies. I. An ultrastructural study of experimental tri-ortho-cresyl phophate intoxication in the cat. J Neuropathol Exp Neurol 28: 571-597

29. Parhad IM, Griffin JW, Clark AW, Koves JF (1984) Doxorubicin intoxication: Neurofilamentous axonal changes with subacute neuronal death. J Neuropathol Exp Neurol 43:188-200

30. Schmidt RE, Scharp DW (1982) Axonal dystrophy in experimental diabetic autonomic neuropathy. Diabetes 31: 761770

31. Schmidt RE, Plurad SB, Modert CW (1983) Experimental diabetic autonomic neuropathy characterization in streptozotocin-diabetic Sprague-Dawley rats. Lab Invest 49:538-552

32. Yagihasi S, Zhang W-X, Sima AAF (1989) Neuroaxonal dystrophy in sensory nerves of the diabetic BB-Wistar rat. J Diab Compl 3: 202-210
33. Mendell JR, Sahenk Z, Warmolts JR, Marshall JK, Thibert P (1981) The spontaneously diabetic BB Wistar rat. Morphologic and physiologic studies of peripheral nerve. J Neurol Sci 52: 103115

34. Medori R, Jenich H, Autilio-Gambetti L, Gambetti P (1988) Experimental diabetic neuropathy: similar changes of slow axonal transport and axonal size in different animal models. J Neurosci 8:1814-1821

35. Bischoff A (1968) Diabetische Neuropathie. Pathologische Anatomie, Pathophysiologie und Pathogenese auf Grund elektronen-mikroskopischer Untersuchungen. Dtsch Med Wochenschr 93: $237-241$

36. Sima AAF, Bouchier M, Christensen H (1983) Axonal atrophy in sensory nerves of the diabetic BB-Wistar rat: a possible early correlate of human diabetic neuropathy. Ann Neurol 13:264-272

Received: 25 September 1991

and in revised form: 24 February 1992

Prof. A.A.F.Sima

Michigan Diabetes Research and Training Center

The University of Michigan

1331 East Ann Street, Box 0580

Ann Arbor, MI 48109-0580

USA 